\title{
VALUE OF PROSTATE SPECIFIC ANTIGEN IN PREDICTING THE EXISTENCE OF BONE METASTASIS IN SCINTIGRAPHY
}

\author{
ERNANI L. RHODEN, OLAVO TORRES, GABRIEL Z. RAMOS, RAFAEL R. LEMOS, \\ CARLOS A.V. SOUTO
}

Section of Urology, Federal Foundation Medical School of Porto Alegre, Hospital da Irmandade da Santa Casa de Misericórdia de Porto Alegre, Porto Alegre, Rio Grande do Sul, Brazil

\begin{abstract}
Objective: Evaluate the ability of serum concentration of prostate specific antigen (PSA) between 2 cutting points to predict the existence of bone metastasis confirmed by bone scintigraphy in man with prostate cancer.

Materials and Methods: Two hundred and fourteen consecutive patients with prostate cancer were evaluated during the present study in the period from 1998 to 2001. From all patients, PSA serum concentrations and bone scintigraphy were obtained. For the study, 2 cutting points of PSA (10 and $20 \mathrm{ng} / \mathrm{mL}$ ) were adopted to predict the existence of bone metastasis.

Results: From the 214 patients, 35 (16.3\%) presented positive scintigraphic examinations for the presence of bone metastasis. No patient presented bone metastasis in scintigraphy if having PSA $<10 \mathrm{ng} / \mathrm{mL}$, and in only 1 patient $(0.46 \%)$ with bone metastasis PSA concentration was $<20$ $\mathrm{ng} / \mathrm{mL}$. Therefore, when the cutting point adopted for PSA serum concentration was $10 \mathrm{ng} / \mathrm{mL}$, a negative predictive value for bone metastasis was $100 \%$ with sensitivity rates of $100 \%$. Nevertheless, the positive predictive value and the specificity of the method were, respectively, $24.5 \%$ and $39.7 \%$. When the cutting point of PSA serum concentration was $20 \mathrm{ng} / \mathrm{mL}$, an increment was observed in rates of positive predictive value and specificity ( $41.5 \%$ and $73.2 \%)$, respectively, without substantial changes in negative predictive value $(99.2 \%)$ and sensitivity $(97.1 \%)$ of the method.

Conclusions: Data of present study allow for the conclusion that PSA serum concentration over $20 \mathrm{ng} / \mathrm{mL}$ was a more accurate cutting point than PSA serum concentration over $10 \mathrm{ng} / \mathrm{mL}$ to predict the presence of bone metastasis in scintigraphy.
\end{abstract}

Key words: prostate; prostatic neoplasms; prostate-specific antigen; neoplasm staging; neoplasm metastasis; skeleton

Int Braz J Urol. 2003; 29: 121-6

\section{INTRODUCTION}

Prostate cancer occupies a prominent place among malignant neoplasias of the genitourinary tract, and currently represents the most common neoplasia, being the second most frequent cause of death by cancer in men (1).

Presently, prostate specific antigen (PSA) is the most accurate test for the diagnosis of prostate adenocarcinoma (2,3-5). For prostate adenocarcinoma, it is admitted that the higher the values of PSA are, the bigger is the volume of tumor existing in the patient, suggesting also a relation that is directly proportional to the tumor stage (2,5-11).

Besides that, among other methods available for evaluating the patient with prostate neoplasia, we can mention prostatic acid phosphatase, alkaline phosphatase, tumor ploidy, Gleason score, ultrasonogra- 
phy, computer tomography, magnetic resonance imaging, and bone scintigraphy, among others (9). Of a particular interest, bone scintigraphy using the radioisotope Technetium (99 mTc) methylene diphosphate remains as the most sensitive method for evaluating the skeleton in bone metastasis diagnosis, being superior to conventional radiological study and to the serum levels of prostatic alkaline phosphatase. This examination presents high sensitivity with low rate of false negatives, and besides that, $43 \%$ of individuals with metastasis detected in scintigraphy can be asymptomatic, $39 \%$ and $23 \%$ can have normal prostatic acid phosphatase and alkaline phosphatase, respectively. Finally, between 10 and 50\% of patients with metastasis detected through scintigraphy present normal radiological studies $(9,11)$.

Scintigraphy has against it the fact of being the most expensive examination to evaluate patients with prostate cancer, costing around 10 times more than PSA determination. Thus, some authors suggest the possibility of using PSA serum levels to predict possible scintigraphic findings $(4,5,8,9,11-13)$. Nevertheless, up to the moment, the literature presents disagreeing results in what concerns the cutting point to be adopted to predict the presence or absence of bone metastasis in prostate adenocarcinoma $(1,10,14,15)$.

The objective of the present study is to evaluate in patients with diagnosis of prostate cancer, the relationship between serum concentration of 2 PSA cutting points and the presence of bone metastasis in scintigraphy.

\section{MATERIALS AND METHODS}

Two hundred and fourteen consecutive patients, with prostate adenocarcinoma, were treated in the period between 1998 and 2001, and were retrospectively analyzed, being their data retrieved from respective records.

All patients were submitted to routine examination, including the determination of PSA serum concentration by using the chemiluminescence method (Ciba-CorningR, Diagnostic Corp, Automated Chemiluminescence System - ACS-180, USA), considering as normal the values between zero and $4 \mathrm{ng} / \mathrm{mL}$.
Exclusion criteria included patients under anti-androgenic treatment previous to the evaluation, patients submitted to radical prostatectomy, patients with vesical catheter, and patients with genitourinary infection.

The diagnosis of prostate carcinoma was established through prostate biopsy guided by transrectal ultrasonography or in the material of prostate transurethral resection performed for presumable benign prostatic hyperplasia. After diagnosis of prostate cancer, all cases were submitted to bone scintigraphy examination. This examination was accomplished between 3 to 4 hours after intravenous injection of $700 \mathrm{MBq} 99 \mathrm{mTc}-m e t h y l e n e$ diphosphonate, and obtaining complete body images (anterior and posterior). Detailed images were obtained when considered as necessary for better viewing of suspected areas, as well as for correlation of these scintigraphic findings with conventional radiological exams or with computer tomography. The radiologist analyzed scintigraphic exams without knowledge of the serum levels of PSA, and they were interpreted as negative or positive for bone metastasis, according to the bone absorption of the radiopharmaceutical.

To determine the rate between PSA serum level and the presence of bone metastasis through scintigraphy, 10 and $20 \mathrm{ng} / \mathrm{mL}$ were considered as the PSA reference values. In each analysis, it has been considered as prognostic PSA serum levels for bone metastasis the values equal or superior to the cutting points, and negative those values inferior to these points.

For statistical analysis, t-Student test and probability tests were used, considering $\mathrm{p}<0.05$ as statistically significant.

\section{RESULTS}

From the 214 patients, $35(16.3 \%)$ presented positive scintigraphic exams in relation to the presence of bone metastasis, and for the remaining 179 cases $(83.7 \%)$ the exams were considered as normal. No patient presented bone metastasis in bone scintigraphy with PSA $<10 \mathrm{ng} / \mathrm{mL}$, and only for 1 patient $(0.46 \%)$ with bone metastasis, PSA concentration was lower than $20 \mathrm{ng} / \mathrm{mL}$. 
Among patients with bone metastasis diagnosis, ages varied from 51 to 80 years $($ mean $=67.7)$ and PSA serum concentrations varied from 13.8 to $500 \mathrm{ng} / \mathrm{mL}$ (mean $=97.7 \pm 81.1 \mathrm{ng} / \mathrm{mL}$ ). In the group of patients without bone metastasis, the ages varied from 53 to 86 years $($ mean $=67.2)$, and PSA serum concentrations varied from 0.5 to $100.5 \mathrm{ng} / \mathrm{mL}$ (mean $=17.5 \pm 17.9 \mathrm{ng} / \mathrm{mL}(\mathrm{p}<0.05)$.

When the cutting point for PSA serum concentration of $10 \mathrm{ng} / \mathrm{mL}$ was analyzed, no patient presented bone metastasis in scintigraphy. Nevertheless, among the 143 patients with PSA > $10 \mathrm{ng} / \mathrm{mL}, 35$ (24.5\%) presented bone metastasis, and the remaining 108 patients $(75.5 \%)$, presented normal scintigraphy. These values evidenced a sensitivity of $100 \%$, absence of false negatives, and a negative predictive value of $100 \%$. The specificity for this cutting point was $39.7 \%$, and the positive predictive value was $24.5 \%$ (Table-1).

One hundred and thirty two patients $(61.7 \%)$ presented PSA inferior or equal to $20 \mathrm{ng} / \mathrm{mL}$, and in one case $(0.75 \%)$ scintigraphy was positive for bone metastasis, while the remaining 131 patients $(99.2 \%)$ presented normal scintigraphy (Table-2). On the other hand, 82 patients $(38,3 \%)$ presented PSA greater or equal to $20 \mathrm{ng} / \mathrm{mL}$, being bone scintigraphy positive for metastasis in 34 patients (41.5\%), and negative in $48(58.5 \%)$. The data showed above analyzed through probability tests indicated a sensitivity of $97.1 \%$ and specificity of $73.2 \%$, and a rate of false positive and negative diagnosis of 41.5 and $99.2 \%$, respectively, with a PSA cutting point of $20 \mathrm{ng} / \mathrm{mL}$, to predict the

Table 1 - Relationship between prostate specific antigen (PSA) concentrations, cutting point of $10 \mathrm{ng} / \mathrm{mL}$, and presence of bone metastasis in scintigraphy for patients with prostate cancer.

\begin{tabular}{lcc}
\hline PSA Concentration & \multicolumn{2}{c}{$\begin{array}{c}\text { Scintigraphy for } \\
\text { Bone Metastasis }\end{array}$} \\
& Positive & Negative \\
\hline & & \\
$\geq 10 \mathrm{ng} / \mathrm{mL}$ & 35 & 108 \\
$<10 \mathrm{ng} / \mathrm{mL}$ & 0 & 71 \\
\hline
\end{tabular}

Table 2 - Relationship between prostate specific antigen (PSA) concentrations, cutting point of $20 \mathrm{ng} / \mathrm{mL}$, and presence of bone metastasis in scintigraphy for patients with prostate cancer.

\begin{tabular}{lcc}
\hline PSA Concentration & \multicolumn{2}{c}{$\begin{array}{c}\text { Scintigraphy for } \\
\text { Bone Metastasis }\end{array}$} \\
& Positive & Negative \\
\hline$\geq 20 \mathrm{ng} / \mathrm{mL}$ & 34 & 48 \\
$<20 \mathrm{ng} / \mathrm{mL}$ & 1 & 131 \\
\hline
\end{tabular}

occurrence of bone metastasis. Odds ratio calculated for PSA equal or greater than $20 \mathrm{ng} / \mathrm{mL}$ in relation to values inferior than this was 92.79 (IC 95\% $=13.02$ to $1,872.30$ ) for the possibility of predicting bone metastasis for prostate cancer.

\section{DISCUSSION}

As bone scintigraphy is normal for the great majority of prostate cancer cases recently diagnosed, normal levels or slight elevations in PSA (lesser than $20 \mathrm{ng} / \mathrm{mL}$ ) should identify a subgroup of patients with low risk for presenting bone metastasis (1). Although our results are in accordance with this statement, they should be regarded with some reservation, i.e., serum levels of PSA inferior to $10 \mathrm{ng} / \mathrm{mL}$ should not be understood as absolute guaranty of bone metastasis absence, but as presenting an extremely low probability, in accordance to the results observed in this series.

What calls the attention is mainly the high negative predictive value found in both cutting points adopted. By considering PSA serum concentration of $10 \mathrm{ng} / \mathrm{mL}$ as reference point for the presence of bone metastasis, negative predictive value reaches a $100 \%$ rate. On the other hand, it is observed an extremely low positive predictive value (24.5\%) to predict the presence of bone metastasis for PSA $\geq 10 \mathrm{ng} / \mathrm{mL}$. These data certainly reflect the low rate of false positive diagnosis when these levels of PSA serum concentration are adopted to predict the occurrence of 
bone metastasis. These aspects are in accordance with observations of other authors like Lobo et al. (16), who in his series of 79 patients with prostate cancer, found for PSA serum concentrations lower or equal to $10 \mathrm{ng} / \mathrm{mL}$, a negative predictive value of $100 \%$ for bone metastasis. Besides these, other series showed a negative predictive value when PSA $<10 \mathrm{ng} / \mathrm{mL}$, from $96 \%$ to $100 \%$, and with a cutting point of $20 \mathrm{ng} /$ $\mathrm{mL}$ it was $94 \%(15,17-19)$.

On the other hand, when a reference point of $20 \mathrm{ng} / \mathrm{mL}$ for PSA serum concentration was adopted, relationships of probabilities and predictive values were slightly altered, i.e., negative predictive value remained very high $(99.2 \%$ versus $100 \%)$, and the sensitivity of the method, equally, was altered in a very slight way $(97.1 \%$ versus $100 \%)$. On the other hand, a significant increment in the specificity of the method $(73.2 \%$ versus $39.7 \%)$ was observed, with a considerable increase too, although still low, of positive predictive value $(41.5 \%$ versus $24.5 \%)$ to predict the presence of bone metastasis for PSA $\geq 20$ $\mathrm{ng} / \mathrm{mL}$.

Oesterling (9) verified in a series of 852 cases of prostate cancer that when concentration of PSA was lesser than $20 \mathrm{ng} / \mathrm{mL}$, only 7 patients $(0.8 \%)$ presented bone metastasis in scintigraphy. Oommen et al. (15) contra-indicate bone scintigraphy in asymptomatic patients with PSA $<10 \mathrm{ng} / \mathrm{mL}$ because cost benefit is not worth.

Disagreeing with the remaining studies published in the literature, Wymenga et al. (1) evaluated the relationship between routine bone scintigraphy in patients with prostate cancer based on serum levels of PSA and alkaline phosphatase. Their findings were that $13 \%$ of patients with PSA < $20 \mathrm{ng} / \mathrm{mL}$ presented positive scintigraphic studies for bone metastasis, and besides that the majority of these cases $(73.4 \%)$ presented serum levels of PSA $<10$ $\mathrm{ng} / \mathrm{mL}$. Perhaps low degree of differentiation in the neoplasias evaluated in the series of these authors can justify these results, which are in disagreement with those found in this study and also in the majority of previously published studies.

From the results obtained and statistical analysis done, it seams that the best cutting point for a serum concentration of PSA to be adopted as a predictor of the presence of bone metastasis in scintigraphic studies would be $20 \mathrm{ng} / \mathrm{mL}$. On the other hand, there is a substantial reduction in the number of exams unnecessarily accomplished for staging individuals with prostate cancer, i.e., in only 1 case $(2,8 \%)$ of prostate cancer and bone metastasis detected through scintigraphy, PSA levels was between 10 and $20 \mathrm{ng} / \mathrm{mL}$.

These conclusions are in accordance with the findings of other authors like Chibowski et al. (11), who observed a positive correlation among local clinic follow up, prostatic acid phosphatase, alkaline phosphatase, PSA, and the findings of bone scintigraphy. Among all these exams, PSA showed to be the most trustworthy for this correlation, with a mean PSA serum level of $11.3 \mathrm{ng} / \mathrm{mL}$ when bone scintigraphy is negative.

\section{CONCLUSION}

The results of present study allow us to conclude that a serum concentration of PSA higher than $20 \mathrm{ng} / \mathrm{mL}$ was a most accurate cutting point than a serum concentration of PSA higher than $10 \mathrm{ng} / \mathrm{mL}$ to predict metastasis in bone scintigraphy. In this way, unnecessary costs can be avoided, since a considerable part of prostate adenocarcinomas present low PSA serum levels $(<20 \mathrm{ng} / \mathrm{mL})$, and for these cases bone scintigraphy could be unnecessary.

\section{REFERENCES}

1. Wymenga LF, Boomsma JH, Groenier K, Piers DA, Mensink HJ: Routine bone scans in patients with prostate cancer related to serum prostate-specific antigen an alkaline phosphatase. BJU Int. 2001; 88: 226-30.

2. Stamey TA, Yang N, Hay AR, McNeal JE, Freiha FS, Redwine E: Prostate-specific antigen as a serum marker for adenocarcinoma of the prostate. N Engl J Med. 1987; 317: 909-16.

3. Catalona WJ: Management of cancer of prostate. $\mathrm{N}$ Engl J Med. 1994; 331: 996-1004.

4. Pollack A, Zagars GK, El Naggar AK, Terry NH: Relationship of tumor DNA-ploidy to serum prostatespecific antigen doubling time after radiotherapy for prostate cancer. Urology 1994; 44: 711-8. 
5. Srougi M: Prostate Specific Antígen. In: Srougi M (ed). Prostatic Hyperplasia. Rio de Janeiro, Record. 1995; cap.5, pp. 89-111 [in Portuguese].

6. Partin AW, Yoo J, Carter HB, Pearson JD, Chan DW, Epstein Jr, et al.: The use of prostate specific antigen, clinical stage and Gleason score to predict pathological stage in men with localized prostate cancer. J Urol. 1993; 150: 1923-4 (Letter).

7. Partin AW, Yoo J, Carter HB, Pearson JD, Chan DW, Epstein Jr, et al.: The use of prostate specific antigen, clinical stage and Gleason score to predict pathological stage in men with localized prostate cancer. J Urol. 1993; 150: 110-4.

8. Stamey TA: Editorial: The central role of prostate specific antigen in diagnosis and progression of prostate cancer. J Urol. 1995; 154: 1418-9.

9. Oesterling JE: Using PSA to eliminate the staging radionuclide bone scan. Urol Clin North Am. 1993; 20: 705-11.

10. Hering FLO, Srougi M: Prostate adenocarcinoma: correlation between preoperative serum PSA, extraprostatic disease and tumor progression. J Bras Urol. 1995; 21: 51-3 [in Portuguese].

11. Chybowski FM, Keller JJL, Bergstralh EJ, Oesterling JE: Predicting radionuclide bone scan findings in patients with newly diagnosed, untreated prostate cancer: prostate antigen is superior to all other clinical parameters. J Urol. 1991; 145: 313-8.

12. Dalkin BL, Ahmann FR, Kopp JB: Prostate specific antigen levels in men older than 50 years without clinical evidence of prostatic carcinoma. J Urol. 1993; 150: 1837-9.
13. Brawer MK, Beatie J, Wener MH, Vessella RL, Preston SD, Lange PH: Screening for prostatic carcinoma with prostatic specific antigen: results of the second year. J Urol. 1993; 150: 106-9.

14. Carrol P, Coley C, McLeod D, Schellhammer P, Sweat P, Wason J, et al.: Prostate-specific antigen best pratice policy - part II: prostate cancer staging and posttreatment follow-up. Urology 2001; 57: 225-9.

15. Oommen R, Geethanjali FS, Gopalakrishnan G, Chacko N, Jhon S, Kanagasabathy AS, et al.: Correlation of serum prostate specific antigen levels and bone scintigraphy in carcinoma prostate. $\mathrm{Br} \mathbf{J}$ Radiol. 1994; 67: 469-71.

16. Lobo G, Ladron GD, Salgado G, Donoso G, Bagus F: Bone scintigraphy in prostatic cancer. Correlation with clinical and laboratory features and survival. Rev Med Chil. 1999; 127: 181-8 [in Spanish].

17. Wolff JM, Zimmy M, Borchers H, Wildberger J, Buell U, Jacse G: Is prostate-specific antigen a reliable marker of bone metastasis in patients with newly diagnosed cancer of the prostate? Eur Urol. 1998; 33 : 376-81.

18. Haukaas S, Roervik J, Halvorsen OJ, Foelling M: When is bone scintigraphy necessary in the assessment of newly diagnosis, untreated prostate cancer? BJU Int. 1997; 79: 770-6.

19. Cadeddu JA, Pearson JD, Lee BR, Landis P, Partin Av, Epstein JI, et al.: Relationship between changes in prostate-specific antigen and the percent of prostatic epithelium in men with benign hyperplasia. Urology 1995: 45: 795-800.

\footnotetext{
Correspondence address:

Dr. Rafael Rodrigues Lemos

Rua Roberto Hpltermann, 283

Santa Maria, RS, 97015-570, Brazil

Fax: + 5555 222-2798

E-mail: lemosrr@hotmail.com
} 


\section{EDITORIAL COMMENT}

This article by Rhoden et al. treats a frequent question: when shall we request bone scintigraphy to complement the follow up of a recently diagnosed prostate adenocarcinoma?

In fact, the answer to this question is not very clear in literature yet. It is well known that bone scintigraphy is the most accurate imaging examination to detect bone metastasis, being much more precise than simple radiography, computer tomography, and even magnetic resonance imaging, especially for initial lesions. It is estimated that while $50 \%$ of bone marrow has to be already substituted by metastasis in order to be evidenced by simple radiography , only $10 \%$ of it needs to be already substituted to indicate positive findings through bone scintigraphy (1).

The fact of the diagnosis of patients with tumors in initial stages is becoming more and more common, mainly as a result of extensive use of serum PSA determinations, has changed the historical conception of absolute need of bone scintigraphy, especially for patients with low levels of serum PSA. Already classical works by Oesterling, studied by the authors, demonstrated that under the point of view of cost-effectiveness, the probability of positive findings in scintigraphy for patients with PSA levels inferior to 10 or $20 \mathrm{ng} / \mathrm{ml}$ is extremely low, being questionable its indication under these circumstances (2).

Nevertheless, in spite of these concepts, in clinical practice bone scintigraphy remains well requested as follow up exam, even for patients with low PSA (3). This might be true due to other useful information supplied by bone scintigraphy before treatment: data on superior urinary tract function and the supply of a basal study for comparison with fu- ture findings for patients that will present bone pain later (differential diagnostic between arthritis and metastasis), besides stratifying risks for patients with positive lesions.

The study of Rhoden et al. suggests that it might be unnecessary to use the cutting point of 10 $\mathrm{ng} / \mathrm{ml}$ of serum to request scintigraphy, as diagnostic accuracy was better with $20 \mathrm{ng} / \mathrm{ml}$. Nevertheless, the ideal cutting point in its casuistic could only be determined with the use of ROC curves for sensitivity and specificity of the test.

Present literature gives us solid base as to not routinely request bone scintigraphy for the follow up of asymptomatic patients with PSA inferior to 10 or even $20 \mathrm{ng} / \mathrm{ml}$, as demonstrated in the present work. Nevertheless, low morbidity of scintigraphic examination and basic information that it can eventually supply, anyway do not disapprove or condemn the urologist who requests the exam, even for patients with PSA inferior to $10 \mathrm{ng} / \mathrm{ml}$.

\section{References}

1. Montie J: Stanging Systems for Prostate Cancer. In: Vogelzang NJ, Scardino PT, Shipley WU, Coffey DS, Miles BJ (eds). Comprehensive Textbook of Genitourinary Oncology. Blatimore, Williams \& Wilkins. 2000; pp. 673-9.

2. Oesterling JE, Martin SK, Bergstralh EJ, Lowe FC: The use of prostate-specific antigen in staging patients with newly diagnosed prostate cancer. JAMA 1993; 269: 57-60.

3. Kindrick AV, Grossfeld GD, Stier DM, Flanders SC, Henning JM, Carroll PR: Use of imaging tests for staging newly diagnosed prostate cancer: trends from the CAPSURE database. J Urol. 1998; 160: 2102-6.

Dr. Gustavo Franco Carvalhal Section of Urology Catholic University - RS Porto Alegre, Rio Grande do Sul, Brazil 